\title{
- ORAL PRESENTATIONS -
}

\section{A STRATEGIC MODEL FOR IMPLEMENTATION OF INTEGRATED URBAN WATER MANAGEMENT}

Lucian Constantin ${ }^{1}$, Luisa Roxana Popescu ${ }^{1,2}$, Mihaela lordache ${ }^{1}$, Carol Blaziu Lehr ${ }^{1}$

${ }^{1}$ National Research and Development Institute for Industrial Ecology - INCD ECOIND, 71-73 Drumul Podu Dambovitei Street, Sector 6, 060652, Bucharest, Romania

2University "Politehnica" of Bucharest, Faculty of Applied Chemistry and Material Science, 1-7 Gheorghe Polizu Street, 011061, Bucharest, Romania

\begin{abstract}
Integrated Urban Water Management (IUWM) represents an integrated approach that aims to reduce urban water demand from centralised urban water sewerage system through implementation of water consumption reduction management, use of alternative water sources, water recycling and reuse. IUWM is not a scope but rather a tool used to integrate water resources, economic sectors that are using water, water supply - sewerage systems and water management authorities. Based on the three pillars of sustainable development a strategic model for implementation of IUWM within urban areas was developed. For the implementation of proposed IUWM strategic model the following main steps are needed to be undertaken: real diagnosis of the current water management status, setting up the vision, mission and fundamental values, establishment of strategic objectives structured on four perspectives (financial, partners, internal processes, learning/growth) and development of key performance indicators set. An example of proposed IUWM strategic model applied on an urban area is also presented.
\end{abstract}

Keywords: IUWM, strategic model, water resources

\section{Introduction}

Integrated Urban Water Management (IUWM) represents the next step in the development of urban water management having as general purpose the efficient management of urban water cycle in order to achieve more benefits compared with traditional approaches. Three common benefits must be mentioned versus traditional water management [1]:

A more "natural" water cycle. It asks for implementation of decentralised solutions and disconnection of water bodies from urban areas, in such a way 
that their flow rates to be similar with the natural ones, in terms of quality, quantity and frequency, in order to avoid flood risks [2].

Enhanced security of water sources through diversification of available local water sources. Alternative sources include rainwater, storm water collecting and water recycling [3]. Diversification of local water sources reduces fresh water demand from surface and ground water sources enhancing the water security.

Efficiency of resource use. IUWM promotes the efficient use of resources, implying minimisation of water, energy, chemical reagents and other resources consumptions in order to reduce the costs. Beyond the 3Rs (Reduce, Reuse, Recycle), the intention is to minimise the urban water footprint, which involves also the recovery of useful compounds (such as energy, nutrients, water) from wastewater flows [4].

IUWM implies rethinking of urban water systems in order to aggregate and interconnect urban water management components and set up suitable communication channels between coordinating structures, internal departments, local administration, local communities and other stakeholders. IUWM is not a scope but rather a tool to be used for water sources, water-sewerage operators and water management sectors integration taking into consideration the followings [5]:

- Use of alternative water sources,

- Water use based on water source quality,

- Water storage, supply, treatment, recycling, reuse and discharge as parts of water management cycle,

- Protection and conservation of water sources,

- Presence of water users from other sectors that are depending on the same water source,

- Stakeholders awareness,

- Economic efficiency, environmental sustainability and social equity (the triple bottom line of sustainable development).

In order to implement an IUWM approach there is a need to develop an IUWM strategy. The following paragraphs are describing a proposed strategic model for implementation of IUWM.

\section{Methodology}

The strategic model proposed for IUWM implementation as any strategy based on the three pillars of sustainable development includes the following steps:

- Decision on this action and awareness of the whole local community on this intention. Without decision making factors participation any strategy is compromised,

- A real diagnosis of present urban water management system,

- Setting up the strategy vision, the sentence that declares the strategy scope,

- Setting up the strategy mission, the components needed to achieve the strategy vision, 
- Setting up the fundamental values, that includes the ethic coordinates to be adopted by decision making factors for the IUWM strategy implementation,

- Defining strategic objectives and building policies needed to be applied in order to achieve these objectives,

- Setting up the key performance indicators (KPI) set that will be used to assess the achievement of strategic objectives

- Strategy implementation,

- Strategy monitoring, assessment and control

\section{Results and Discussion}

An example of proposed IUWM strategic model development for urban areas is described in the following paragraphs.

a. Vision

For example "Increase of life quality and conservation of water resources at local community level"

\section{b. Mission}

When the mission is set up at least the following area of interests need to be considered:

Table 1 Elements to be considered for the definition of IUWM strategy mission

\begin{tabular}{|l|c|c|c|}
\hline $\begin{array}{l}\text { Consumers } \\
\text { satisfaction beyond } \\
\text { their expectations }\end{array}$ & $\begin{array}{c}\text { Technologies } \\
\text { water using efficient } \\
\text { technologies with } \\
\text { minimum impact upon } \\
\text { the environment }\end{array}$ & Communication & $\begin{array}{c}\text { Socal community } \\
\text { community and its } \\
\text { members }\end{array}$ \\
\hline $\begin{array}{l}\text { Consumers } \\
\text { preservation }\end{array}$ & $\begin{array}{c}\text { Modernisation } \\
\text { Revamping }\end{array}$ & $\begin{array}{c}\text { Incentives / support } \\
\text { for water } \\
\text { management } \\
\text { specialists }\end{array}$ & $\begin{array}{c}\text { Contribution to } \\
\text { economic and social } \\
\text { development of our } \\
\text { partners }\end{array}$ \\
\hline $\begin{array}{l}\text { Correctness, respect, } \\
\text { trust, quick response }\end{array}$ & $\begin{array}{c}\text { Alternative water } \\
\text { sources identification } \\
\text { / use }\end{array}$ & $\begin{array}{c}\text { Better equipment and } \\
\text { working conditions }\end{array}$ & \begin{tabular}{c} 
Zero discharges \\
\hline
\end{tabular} \\
\hline
\end{tabular}

\section{c. Fundamental values}

The following table tries to synthesize the main common action directions together with ethic coordinates to be used by water management system's decision making factors. 
Table 2 Elements for IUWM strategic model constitution

\begin{tabular}{|l|l|}
\hline $\begin{array}{l}\text { Fundamental } \\
\text { values }\end{array}$ & \multicolumn{1}{|c|}{ Content } \\
\hline Business ethics & $\begin{array}{l}\text { We are respecting the business ethics. We don't make compromises. We } \\
\text { respect our duties. }\end{array}$ \\
\hline $\begin{array}{l}\text { Strategy and } \\
\text { management }\end{array}$ & $\begin{array}{l}\text { We are supporting water specialists' contributions. Innovation and } \\
\text { creativity. Flexibility. Efficient use of equipment. }\end{array}$ \\
\hline Water specialists & Incentives and support. Transparency. \\
\hline Partners & $\begin{array}{l}\text { Our consumers - our masters. Trust, mutual respect, cooperation. We try } \\
\text { to fulfil our consumers' expectations and requests. }\end{array}$ \\
\hline Communication & $\begin{array}{l}\text { Both vertical and horizontal communication. We are open to suggestion } \\
\text { and critics. }\end{array}$ \\
\hline Working conditions & $\begin{array}{l}\text { Better equipment and working conditions. Work safety. Clean working } \\
\text { environment. }\end{array}$ \\
\hline Investors & We try to attract the investors. We don't take any dangerous risks. \\
\hline Local authorities & $\begin{array}{l}\text { We understand their concerns and try to respond to their needs and } \\
\text { requests. Win-win cooperation. }\end{array}$ \\
\hline Local community & $\begin{array}{l}\text { We listen to our neighbors' demands and respond to their needs and } \\
\text { problems. We count on our community support to build our success within } \\
\text { the water management sector. }\end{array}$ \\
\hline
\end{tabular}

\section{d. Strategic objectives}

A strategic model based on sustainable development principles must contain four essential components:

- Social progress that takes into consideration the needs and aspirations of each individual,

- An efficient protection of the environment,

- Cautious use of natural resources,

- Stable and balanced development at both economic and social level.

In other words, such a strategic model needs to be structured taking into consideration the three pillars of sustainable development.

On the other hand, strategic objectives must consider the four perspectives inspired by Balanced Scorecard model developed by Kaplan and Norton [6]:

- Financial,

- Partners,

- Internal processes,

- Learning and growth.

A strategic map is structured that way. At the intersection of lines (perspectives) with columns (sustainable development pillars) strategic objectives are defined. The proposed strategic map presented in figure 1 is including possible objectives to be addressed by an IUWM approach. 


\begin{tabular}{|c|c|c|c|c|c|c|}
\hline & & \multicolumn{5}{|c|}{ STRATEGIC TARGET: What urban water management system want to achieve by 2020} \\
\hline \multirow{4}{*}{ 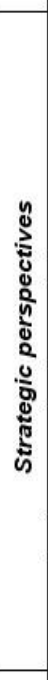 } & Financial & $\begin{array}{l}\text { Sound } \\
\text { circulation of } \\
\text { funds }\end{array}$ & $\begin{array}{l}\text { Investment in } \\
\text { green } \\
\text { technologies }\end{array}$ & $\begin{array}{c}\text { Investment in } \\
\text { alternative } \\
\text { water sources } \\
\text { and measures } \\
\text { for reduction of } \\
\text { water } \\
\text { consumption }\end{array}$ & Green community & $\begin{array}{l}\text { Communication and } \\
\text { awareness }\end{array}$ \\
\hline & Partners & $\begin{array}{c}\text { Trust of } \\
\text { traditional } \\
\text { consumers }\end{array}$ & New consumers & $\begin{array}{c}\text { Higher value } \\
\text { added services }\end{array}$ & $\begin{array}{c}\text { Good quality of } \\
\text { water resources }\end{array}$ & Actions for community \\
\hline & $\begin{array}{l}\text { Internal } \\
\text { processes }\end{array}$ & $\begin{array}{l}\text { BAT alignment } \\
\text { ISO } 9000\end{array}$ & $\begin{array}{l}\text { State of art } \\
\text { technologies }\end{array}$ & $\begin{array}{l}\text { Integration of } \\
\text { urban water } \\
\text { system } \\
\text { components }\end{array}$ & ISO 14000 & $\begin{array}{l}\text { Better working } \\
\text { conditions }\end{array}$ \\
\hline & $\begin{array}{l}\text { Learning } \\
\text { and growth }\end{array}$ & $\begin{array}{l}\text { Capitalization of } \\
\text { specialists skills }\end{array}$ & $\begin{array}{l}\text { Alternative water } \\
\text { sources }\end{array}$ & $\begin{array}{c}\text { Use of water } \\
\text { resources } \\
\text { based on their } \\
\text { quality }\end{array}$ & $\begin{array}{l}\text { Continuous } \\
\text { training }\end{array}$ & $\begin{array}{c}\text { Popularization of IUWM } \\
\text { actions }\end{array}$ \\
\hline & & Consolidation & Differentiation & Diversification & Environment & Social \\
\hline & & \multicolumn{5}{|c|}{ Economic } \\
\hline
\end{tabular}

Figure 1 Proposed IUWM strategic map

When strategic objectives are defined, decision making factors should take into consideration both their intentions (quantified in monetary values or percentages) but also their infrastructure and capability to sustain the intentions, which sometimes cannot be quantified (such as: capitalization of specialists skills or trust of traditional consumers).

The economic development pillar was split in three components:

- Consolidation,

- Differentiation,

- Diversification.

In formulation of strategic objectives, the decision making factors must consider both to close inefficient activities and to diversify activities based on customers' demands. The differentiation attribute must convince the consumers that water services have their well-defined place in the economic environment, which bring benefits for market and consumers.

\section{e. Strategy metrics}

Each strategic objective must be accompanied by one or more key performance indicators (KPIs). When building the KPIs set the following aspects must be considered:

- KPI must completely characterize strategic process and its dynamic,

- The number of KPls should not be higher than 25 in order to be easy to calculate and monitor by decision making factors, 
- There are lagging indicators calculated at the end of time period (such as water consumption per capita) and leading indicators that are looking forward challenging the specialists to find proper actions for their achievement (such as the number of new consumers),

- Tangible KPIs can be easily calculated in general and numeric values are attached to them. However, in the last years there is a trend to use KPIs that are linked to intangible domains (such as quality of water services, consumers' trust and satisfaction). In these conditions, inclusion of such intangible KPIs is a must,

- Intensive KPIs (such as specific consumptions) are preferred to the extensive ones (absolute values),

- KPls set must be built starting from the water management indicators that are already in use,

- KPls must be accompanied by operational indicators (to be developed in a top-bottom approach) down to lower implementation levels.

\section{f. Strategy implementation}

Transposing strategic objectives into practice asks for clear targets for each objective with deadlines and delegation of responsibilities. Responsible persons should be free to form their implementation teams, set up action plans and take the needed measures.

From this moment top decisional factors have only the tasks to coordinate and monitor all actions plans and allocate resources based on strategic priorities.

In order to exemplify this step, 22 technical options were generated and assessed based on seven criteria, which cover technical/economic, environmental and social aspects:

- Ease of implementation from the technical point of view,

- Estimated economic benefits,

- Conservation of water resources,

- Reduction of water bodies pollution,

- Other environmental benefits,

- Issues related to approvals, permits,

- Social impact,

- Social and cultural issues.

A multi criterial analyze was undertaken based on these seven criteria and the results are presented in table 3. 
Table 3 Multi criterial analyze of proposed IUWM options

\begin{tabular}{|c|c|c|}
\hline No & Option & Score \\
\hline 1 & Rainwater collection and use for toilet flushing and laundry & 123 \\
\hline 2 & Rainwater collection and use for recharging underground water sources & 127 \\
\hline 3 & Rainwater collection and use for streets cleaning, parks sprinkles & 122 \\
\hline 4 & Rainwater collection and use for agricultural purposes, irrigation & 119 \\
\hline 5 & Use of grey water for public toilets & 119 \\
\hline 6 & Reuse of treated wastewater in agriculture, irrigation & 119 \\
\hline 7 & Wastewater local treatment and recycling for non-potable use & 123 \\
\hline 8 & Treated wastewater use for recharging underground water sources & 123 \\
\hline 9 & $\begin{array}{l}\text { Storm water collection from roads, parking spots, sport fields and use for } \\
\text { streets cleaning, parks sprinkles }\end{array}$ & 131 \\
\hline 10 & $\begin{array}{c}\text { Storm water collection from roads, parking spots, sport fields and use for } \\
\text { recharging underground water sources }\end{array}$ & 127 \\
\hline 11 & Separate rainwater sewerage network & 127 \\
\hline 12 & Separate grey water sewerage network & 123 \\
\hline 13 & $\begin{array}{l}\text { Awareness and implementation of water consumption reduction measures } \\
\qquad \text { at final consumer level }\end{array}$ & 138 \\
\hline 14 & Information campaign on integrated urban water management issues & 130 \\
\hline 15 & Development of a local integrated urban water management plan & 132 \\
\hline 16 & Building of rainwater / storm water treatment capacities & 123 \\
\hline 17 & Building of rainwater / storm water storage capacities & 123 \\
\hline 18 & Building of grey water storage capacities & 119 \\
\hline 19 & $\begin{array}{l}\text { Implementation of small decentralised installations for water supply and } \\
\text { wastewater treatment }\end{array}$ & 120 \\
\hline 20 & Local composting installations & 123 \\
\hline 21 & Gardens on buildings' roofs & 132 \\
\hline 22 & Total or partial closing of water cycle when is possible & 128 \\
\hline
\end{tabular}

The next step was to develop an action plan model based on strategic map and proposed options.

The action plan consists of 40 identified options (22 technical options presented in table 3 are included). 
An excerpt from the proposed action plan is presented in table 4 .

Table 4 Proposed action plan for IUWM implementation (excerpt)

\begin{tabular}{|c|c|c|c|}
\hline Strategic objective & Options & $\begin{array}{c}\text { Performance } \\
\text { indicator }\end{array}$ & Target \\
\hline Green community & $\begin{array}{l}\text { Development of a local } \\
\text { integrated urban water } \\
\text { management plan }\end{array}$ & Local IUWM plan & $\begin{array}{l}\text { Up to date local } \\
\text { IUWM plan }\end{array}$ \\
\hline \multirow[t]{2}{*}{$\begin{array}{l}\text { Communication and } \\
\text { awareness }\end{array}$} & $\begin{array}{c}\text { Awareness and } \\
\text { implementation of water } \\
\text { consumption reduction } \\
\text { measures at final } \\
\text { consumer level } \\
\end{array}$ & $\begin{array}{c}\text { Information } \\
\text { campaign } \\
\text { Water consumption } \\
\text { reduction measures } \\
\text { implemented } \\
\end{array}$ & $\begin{array}{c}\text { \% from population } \\
\text { number of } \\
\text { implemented } \\
\text { measures / water } \\
\text { savings } \\
\end{array}$ \\
\hline & $\begin{array}{c}\text { Information campaign on } \\
\text { integrated urban water } \\
\text { management issues }\end{array}$ & $\begin{array}{c}\text { Awareness and } \\
\text { communication } \\
\text { campaign }\end{array}$ & $\%$ from population \\
\hline New consumers & $\begin{array}{c}\text { Attracting new } \\
\text { consumers }\end{array}$ & $\begin{array}{c}\text { Number of new } \\
\text { consumers }\end{array}$ & number \\
\hline \multirow{5}{*}{$\begin{array}{l}\text { Higher value added } \\
\text { services }\end{array}$} & $\begin{array}{c}\text { Building of rainwater / } \\
\text { storm water treatment } \\
\text { capacities }\end{array}$ & $\begin{array}{l}\text { Installations } \\
\text { capacity }\end{array}$ & $\mathrm{m}^{3}$ \\
\hline & $\begin{array}{l}\text { Building of rainwater / } \\
\text { storm water storage } \\
\text { capacities }\end{array}$ & Storage capacity & $\mathrm{m}^{3}$ \\
\hline & $\begin{array}{l}\text { Building of grey water } \\
\text { storage capacities }\end{array}$ & Storage capacity & $\mathrm{m}^{3}$ \\
\hline & $\begin{array}{l}\text { Local composting } \\
\text { installations }\end{array}$ & $\begin{array}{l}\text { Installations } \\
\text { capacity }\end{array}$ & tons \\
\hline & $\begin{array}{l}\text { Gardens on buildings' } \\
\text { roofs }\end{array}$ & Gardens area & ha \\
\hline $\begin{array}{l}\text { Good quality of water } \\
\text { resources }\end{array}$ & $\begin{array}{l}\text { Full time monitoring of } \\
\text { water quality indicators }\end{array}$ & $\begin{array}{l}\text { Compliance } \\
\text { indicators }\end{array}$ & 0 non-compliances \\
\hline Actions for community & $\begin{array}{l}\text { Implementation of small } \\
\text { decentralised installations } \\
\text { for water supply and } \\
\text { wastewater treatment }\end{array}$ & $\begin{array}{l}\text { Number of } \\
\text { installations } \\
\text { Installation } \\
\text { capacities } \\
\end{array}$ & $\begin{array}{c}\text { number } \\
\mathrm{m}^{3}\end{array}$ \\
\hline
\end{tabular}

The proposed IUWM strategic model is finishing its mission at that point. From now on there is the duty of operational management level to replicate action plans, using a top bottom approach, to each generated option being possible to attach one or more actions.

For example, Option 13 - Awareness and implementation of water consumption reduction measures at final consumer level:

- Action 1: Control of water pressure based on water demand,

- Action 2: Installation of flow restrictors for sinks, showers,

- Action 3: Personnel training on water consumption reduction measures,

- Action 4: Purchase of cleaning equipment for grit stone surfaces.

The presented list of actions is not exhaustive, all the ideas of water management specialist can be capitalize and the list can be further filled with more specific actions based on each water use characteristic. 


\section{Conclusions}

Starting from sustainable development paradigm, a strategic model for IUWM implementation was proposed. The strategic model contains the following main components:

- Real diagnosis of present situation,

- Vision,

- Mission,

- Fundamental values,

- Strategic objectives structured on four perspectives:

$\circ$ Financial,

- Partners,

- Internal processes,

- Learning and growth

and triple bottom line of sustainable development:
- Economic,
○ Environment,
- Social,

- Strategic model metrics.

\section{Acknowledgements}

The authors acknowledge the financial support from the Ministry of Education and Scientific Research - National Authority for Scientific Research and Innovation, through the project PN 09-13 02 22, the work done by Luisa Roxana Popescu has been supported by the Sectoral Operational Programme Human Resources Development (SOP HRD), financed from the European Social Fund and the Romanian Government under the contract number POSDRU/159/1.5/S/137390.

\section{References}

[1] D. Marlow, M. Moglia, S. Cook and D. Beale, (2013), "Towards sustainable urban water management: A critical reassessment," Water Research, vol. 47, pp. 71507161.

[2] E. Rozos and C. Makropoulos, (2012), "Assessing the combined benefits of water recycling technologies by modelling the total urban water cycle," Urban Water Journal, vol. 9, no. 1, pp. 1-10.

[3] T. Wong and R. Brown, (2009), "The water sensitive city: principles for practice," Water Science and Technology, vol. 60, no. 3, pp. 362-377.

[4] S. Burn, S. Maheepala and A. Sharma, (2012), "Utilising integrated urban water management to assess the viability of decentralised water solutions," Water Science and Technology, vol. 66, no. 1, pp. 362-377.

[5] V. lacob, (2013), "The wastewater - a problem of integrated urban water management," Procedia Economics and Finance, vol. 6, pp. 436-443.

[6] R. Kaplan and D. Norton, (1997), The Balanced Scorecard - translating strategy into action, Harvard Business School Press. 